KYRYL DZIHORA,

\title{
CENSORSHIP IN SOCIAL NETWORKS AS A SOCIAL PRACTICE IN THE CONTEXT OF GLOBAL TRANSFORMATIONS
}

\begin{abstract}
The article clarifies the socio-philosophical nature of censorship, the methods of its action and the restrictions it may impose on the information presented on social networks. Using specific examples from the work of social networks, the author argues that censorship creates the availability of information. The problem of user's subjectivity in the virtual space have been described. The complexity and contradiction of the phenomenon of censorship on the Internet have been disclosed. Technical, non-technical and indirect methods of implementing censorship frameworks for information in cyberspace have been analyzed. The technical methods are described in more detail in the article. They were grouped according to the following classification: methods that slow down the operation of services; methods that block the activity of services; methods that block information with human participation; methods that block information using algorithms; marking information as unreliable It is stated that censorship today complicates access to information instead of completely blocking it. The problem of new type of censorship on the Internet created by the recommendation systems have been considered. It is noted that the use of these systems enhances the subjectivity of users, and leads to the creation of echo cameras. Thus, the research hypothesis stating that "availability of information generates censorship" was confirmed with the above arguments and examples from the work of social networks.
\end{abstract}

Key word: Internet censorship; information openness; post-truth; censorship methods; crisis in society; internet technology.

Introduction

The global transformations we witness are affecting the lives of all mankind. They can be objective in nature, or they can be caused by the subjective purposeful actions of certain actors. More and more we can see, to some extent, the manageability of global processes. If the subjective management of globalization does not correspond to the objective laws of its development, we will face a situation when global transformations are accompanied by contradictions and unexpected paradoxical manifestations. It is known that information technology is a component of the globalization of the social network system, because without technological modernization of the communication process it is impossible to create more powerful systems for collecting, processing, transmitting and disseminating information. It is social networks that bear the imprint of the objective and the subjective in global transformations. Objectivity lies in the fact that the development of information technology is mainly scientific and technical, subjectivity is manifested in arbitrariness, social irresponsibility, lack of ethical standards. An example is the Internet. Information flows are spontaneous, it is difficult to verify the truth of information, on the contrary, the emotional color of information is enhanced, thus forming the post-truth. In large information flows, control over information becomes more difficult. Paradoxically, censorship on the Internet is gaining momentum these days.
Censorship on the Internet is a very controversial process. On the one hand, we have powerful technologies for disseminating information around the world, on the other hand, we see that these technologies sometimes spread propaganda or even false information. It is clear that states have begun to impose censorship on the Internet, although such actions are not always aimed at protecting citizens, more often it is a solution to political issues. Censorship of information by states is not uncommon, so it is not surprising. But it should be noted that the platforms themselves that disseminate information have begun to apply censorship. However, if we look at the goals and values of such giants as Facebook and Twitter, we will see that these platforms are designed for open dialogue and maximum representation of public opinion. Therefore, we put forward the following thesishypothesis: the availability of information generates censorship.

\section{Methodological basis of the research}

The methodological basis of the article is T.M. Muzhanova's work "Internet censorship as a threat to the rights of citizens in the field of information security" (2015), which provides a classification of censorship methods. This allowed to analyze censorship methods on the Internet, provide them with qualifications and illustrate social network practices. 
The second work that became the methodological basis of our study is Ken Wilber's work of "Trump and a Post-Truth World" (2019). This work shows the correlation of network and political practices in modern political life, which leads to distortion of information in the post-truth format. The third methodological source is Cathy O'Neil's work "Weapons of math destruction: how big data increases inequality and threatens democracy" (2020), which provides a clearer understanding of how data analysis methods are used in modern life, how valuable information is extracted from them and new knowledge is formed; what nonlinear algorithms are used in analytical processes.

The purpose of this study is to find out the essence of censorship and its methods in social networks.

\section{Result and Discussion}

The issue of censorship on the Internet is relevant for the scientific and philosophical community today. Thus, T. Muzhanova (2015: 86) analyzes it in terms of technological solutions. Yu. Pichugina (2011: 251-252) ) studies the modern discourse on the problem of censorship in general, namely censorship on the Internet, artistic censorship, censorship in the aspect of social communications. A. Demutska (2021: 36-37) considers the impact of Internet technology on the mass emotions of people. Researcher O. Kholod (2013: 288-292) considers the concept of social communication in the scientific field and the development of this concept.

A team of foreign scientists Bill Marczak, Nicholas Weaver, Jakub Dalek, Roya Ensafi, David Fifield, Sarah McKune, Arn Rey, John Scott-Railton, Ron Deibert, and Vern Paxson described in great detail the principles of the "China's Great Cannon" (2015: 1). We should also note that there are annual reports on censorship issues in general, namely: Reporters Without Borders (2020) and Freedom House (2020).

At the beginning of our theoretical exploration, we should try to find an event in the past that would be related to the wave of information dissemination among ordinary people. To some extent, this will help to show that the problems we face today are not new, although they have a slightly different scale. There have been many such events, but we will focus on the Reformation. It is there, in the time of Martin Luther, that we can find those parallels with the present that are critical to us. One of the key points of the Reformation was the translation of the Bible into national languages. This allowed the general public to freely master and interpret the Scriptures. That is, it was an act of disseminating information that was previously difficult or impossible to access. Even more, the heyday of the Reformation coincided with the rapid development of printing, the importance of which was noted by Martin Luther himself (Parish, 2018: 58-72). This availability of the Bible raised many questions of a theological nature. The contradictions that arose in resolving these issues led to enmity between Protestants. Moreover, this enmity went far beyond simple heated discussions, reaching human casualties. In this case, Protestants, unable to overcome internal contradictions, resorted to methods of combating dissent, which were practiced by medieval Catholicism. That is, you can see how what seemed good from the beginning, gradually begins to drown in internal contradiction.

This idea is not new, it is somehow clearly traced in many defining events of mankind: whether we consider the French Revolution (1789) or the October Revolution (1917) (Magun, 2011: 381). Johan Huizinga also noted in a broad sense that modern cultural achievements carry symptoms of degeneration and decline (Huizinga, 2010: 111-113). In our case, a new round in access to information and its interpretation also creates contradictions, but now they are related to almost all spheres of life. However, this does not quite answer the question of why social networks began to introduce censorship, and in general, how it works in our technological age.

Talk about censorship cannot be complete without understanding what methods and principles of censoring information exist today. This is very important because the rapid development of technology is constantly expanding the methods of influencing society. Let us use the classification of censorship methods provided by T.M. Muzhanova in her article "Internet censorship as a threat to the rights of citizens in the field of information security" (2015). It should also be noted that the methods to be considered are used together and complement each other.

1. Non-technical methods.

2. Technical methods.

3. Indirect methods.

T.M. Muzhanova defines non-technical methods as those which can legally or physically influence people or institutions involved in the dissemination of unwanted information. A striking example is the recent blocking of the "Zlk", "112", and "NewsOne" channels on YouTube, which was made after the adoption of the package of sanctions by the National Security and Defense Council of Ukraine (Radio Svoboda Ukrayina, 2021, April 24).

Technical methods are methods that directly affect Internet resources or applications, i.e. they can change the state of work of services. The use of these methods can be aimed both at individual information in a particular region and at the service in general. Given the specificity of the impact on information, it is necessary to consider these methods of censorship in more detail. Because there are no boundaries to technology, their impact is felt everywhere.

Omitting some technical details, we can distinguish the following types of technical methods.

1. Methods that slow down the operation of services;

2. Methods that block the activity of services;

3. Methods that block information with human participation;

4. Methods that block information using algorithms;

5. Marking information as unreliable.

Let us consider each type sequentially.

The first type is used as a tool to influence the organization with a particular service. It is very important for users how fast the site or application responds (Spero, 2017: 2), and if it is insufficient, the company begins to lose users, which is equivalent to losing money. The most relevant example is the slowdown of the social network Twitter in Russia (Radio Svoboda Ukrayina, 2021, April 5). It was a successful act of forcing Twitter to delete certain information for users from Russia. Slowing down 
may not always work: if the company is large enough, it can withstand the extra load without losing performance.

The second type of methods is designed to completely block services, sites, applications. As a rule, these are local actions such as blocking social networks and search engines in Ukraine in 2017. But this is not the only example: in some countries, the social network Facebook is blocked. Although such a block cannot be called complete, as users have the ability to bypass the block. One method is to use a VPN (virtual private network). However, in some countries VPN services may be illegal. For example, in Russia and China, such services are partially banned.

The third type of methods is used when content posted on the Internet violates local law or violates the rules of the service where it is located. There are also many examples. As mentioned above, this is a blocking of YouTube channels, a rather loud blocking of Facebook and Twitter accounts of the 45th US President Donald Trump. And in this case, the platforms went even further - they also blocked accounts that retransmitted statements by Trump from his official website.

Sometimes, strange things are censored: the Spotify service censored a playlist of the user who allegedly insulted the Queen of Malaysia, and the blocking occurred every time the user re-created playlists (Sytnikova, 2021). Content can also be blocked when it violates the rules of the platform. The most significant in this sense is Twitch, the platform for video streaming, which differs from others by its rather strict policy. This platform mainly hosts online broadcasts of various events, although the platform itself specializes in computer games. This platform is a leader in the video streaming market, it has 450 million users. What matters to us is why the company blocks access to the content. Blocking can be earned by using forbidden words, their list is constantly updated. If a forbidden word appears on the broadcast in some way, this broadcast will be blocked. This system began to be used to eliminate competitors. Also, people who conduct broadcasts can be blocked if their behavior in real life will violate the rules of the platform. On the one hand, such rules seem logical, because they allegedly educate those people who are engaged in broadcasts to a large audience. On the other hand, analyzing the news about the blocking in this network, the situation seems a bit strange. It should be noted that the basic information broadcast by this site is not critical, so the very fact of the existence of strict control by the corporation is somewhat frightening.

The fourth type of methods raises a very important and popular topic of machine learning and neural networks. The breakthrough in big data processing has made it possible to successfully use algorithms and computers to filter content. It is clear that the array of data generated by users on a daily basis cannot be tracked manually, and algorithms have been developed that can block certain information in terms of its content. For example, Facebook can block advertising posts that are not paid for by the user, that is, without a human, algorithm can independently understand where the advertising post is and where it is not. Text analysis algorithms are very developed today. They can block content according to many different indicators. Sometimes this leads to curious situations. For example, Twitter algorithms in 2018 began to block users who used Cyrillic in their messages (Cnews, 2018, May 23). The algorithm believed that everyone who used Cyrillic was an extremist. Also in 2021, Twitter blocked users' tweets with the word "Memphis" (Cnews, 2018), why this happened is still unclear. Facebook recently deleted posts with the tag "\#ResingModi", which had political significance for India, and later renewed all posts, calling their actions erroneous. There is a lot of news on these topics, because blocking content is a daily occurrence today. What is important here is the use of algorithms based on big data. At present, the prevailing opinion in society is that algorithms have no prejudices, they are fairer than people and, in general, that big data do not lie. And this is a very wrong and harmful idea. Cathy O'Neil, a database researcher and author of mathbase.com, introduces the concept of Mathematical Destruction Weapon (WMD) (O'Neill, 2020: 20), algorithms that increase inequality or social polarization by analyzing big data. Although the term can be called somewhat extravagant, it still accurately reflects the essence of the problem. In her book, she gives many examples of the use of algorithms based on the analysis of data that harm society, but because of the complexity of their work, society itself perceives the results of these algorithms as something absolutely true. A good example would be the use of data analysis to calculate the risk of recidivism, so-called recurrence models. These models, analyzing information about a person, can provide a prediction about the possibility of recidivism by that person. At first glance, the idea does not seem bad, because the algorithm cannot be biased. But it turns out that people from "colored" and poor areas suffer from it more often. Therefore, there is a closed cycle, where people in a difficult situation receive a harsher sentence, but this approach does not solve the problem. A person who is at high risk of recidivism finds himself in prison for a longer period of time, and after leaving it returns to his area in the same difficult situation. It is clear why such people have a higher rate of relapse, but they do not receive help, so in this case the algorithm enhances the differentiation of people (O'Neill, 2020: 48-51). O'Neil identifies three reasons why algorithm solutions cannot be trusted (O'Neill, 2020: 43-54):

1. Using a simplified model of the world.

2. Opacity of algorithms (it is not always clear how the data affect the result).

3. Algorithms are simply the embodiment of human views in program code.

It should be noted that algorithms can learn and thus they can become more objective than humans. But why they learn depends entirely on the views of the people who develop them. Currently, the use of algorithms for censorship is quite moderate, but we already have examples of the use of WMD in everyday life, which greatly complicates people's lives. Although, in Ukraine the problem of WMD application still needs research. Today, there are services that use data analysis for business decisions in Ukraine. Thus, Kyivstar provides such services. According to their website, they helped Monobank reduce the number of problem borrowers. Moreover, it was noted that they increased the percentage of loans to people without a credit history, but the percentage itself is not specified. This information is important because we do 
not know what data they use for analysis, and therefore there are grounds for the formation of WMD (Big Data from Kyivstar). It is too early to draw any serious conclusions, but Cathy O'Neil has shown that relying entirely on data analysis is not always the right result. That is why shifting responsibility to algorithms for choosing whether the information is true or not is not a good solution to the problem.

The fifth point, marking information as inaccurate, marks questionable information with a label that issues a warning on the basis of algorithms. Now, the information about COVID-19 is marked this way the most often. As part of a Facebook experiment, I subscribed to a group that unites people who oppose vaccination. The information posted there is not just questionable, it is openly fake. But almost all records are marked with labels about the need to read the official data on this issue. Also, the news feed is constantly updated with information from the Ministry of Health of Ukraine and the WHO. In this case, such an approach can have a positive impact and somehow introduce people to the alternative, although the news from the group is also published in the feed. We should note the fact that the complexity of the algorithm for issuing information on Facebook does not allow to say how the information will be displayed on another account. This algorithm takes into account a very large number of factors, so in each case the intensity of removal of posts from the group may be different. Here it can also be seen that receiving information in this form, a person may perceive it as equally true. We see how information openness brings even more confusion and uncertainty into our lives. Simple events provoke a stormy reaction, generating a huge flow of information, and this flow is constantly supplemented by marketers and political scientists with their messages. Yuval Noah Harari successfully comments on this situation, noting that previously the government provided access to information, but today the government provides knowledge about what should not distract (Harari, 2018: 464). In a situation where it is very difficult or impossible to distinguish between truth and lies, the emotional coloring of the material is especially important. It should be emphasized that the emotional presentation of information affects not only the user but also the mass of people in general, forming a massive emotional reaction, which can have a physical manifestation in the specific actions of individuals (Demutska; 2021: 37). Thus, the post-truth era becomes very threatening precisely because of the inability of society to adequately respond to the emotionality of information. And due to the fact that the algorithms study us carefully, there is information that can cause a violent reaction of everyone, regardless of gender, race or education.

Further indirect methods of censorship also should be considered. These are covert methods, such as creating pseudo-resources, tracking and storing user data, or attacking sites. Anything can be used, even simple pictures on the Internet or memes can contain the necessary instructions. V. Dodonova's publication (2019: 258-260) describes the use of memes in political agitation quite clearly.

For example, China has powerful tools to influence information. The Golden Shield project, or Great Chinese Firewall, includes all the censorship techniques described above, and even the "Great Cannon of China", which is a tool for attacking sites or individuals that has already been applied to GitHub. Pages detailing how to circumvent censorship in China were attacked (Marczak, Weaver, Dalek, Ensafi, 2015: 1).

The censorship methods described above are used by states and private institutions to restrict the dissemination of "harmful" information. That is, despite the latest technical means, these methods can still be considered "classic". Their use rather complicates access to information, because there may always be the possibility of bypassing the block. The use of all these methods also attracts a lot of attention today. The public resonance causes rather opposite effect. People are becoming even more interested in forbidden information. It should be noted that recent studies of the subconscious also show that direct prohibition affects people as a call to opposite action (Mlodinow, 2020: 215-217).

In general, the information that appears on the Internet once is very difficult to delete completely. Thus, blocking Ukrainian TV channels "Zlk", "112", "NewsOne" on YouTube still does not block information from these channels for users. Reports can be accessed from other channels, which simply retransmit them in the record, they are also available on other services and sites. Also, deleting records by algorithms can also be bypassed by providing information in other way or by transferring it to another platform.

Thus, on the one hand, we have the tools to overcome ignorance. In this case, free access to information provides great opportunities for cooperation and public dialogue. On the other hand, freedom of information leads to the spread of fakes and propaganda. Thus, V.I. Dodonova notes that it is Internet technologies that have contributed to the wide dissemination of post-truth (Dodonova, 2019: 358). The following example demonstrates this situation very well. In 2016, when requesting "whether there really was a Holocaust" in English Google, the first link was the article entitled "Top-10 reasons why the holocaust didn't happen". And this also concerned topics of racism or sexism. That is, when a person made a request, he received not true information, but simply confirmation of his erroneous opinion on these issues (Wilber, 2019: 22-25). Now the algorithm has been modified to correct the retrieval of information to users on these topics, but the basic principles of the system have not changed. It is clear that the list of topics on which people may have conflicting ideas is much larger than those mentioned above. This is a small example and it is only related to Google, but there are other search engines that process information in their own way. Social networks are also full of different communities that generate much provocative content.

The issue of the influence of social networks on the opinion of the average citizen has attracted particular attention after the US presidential election in 2016. The implementation of censorship was, in some ways, a matter of time and later led to the blocking of the accounts of US President Donald Trump in 2020, which was in fact a rather serious step. And all is not well with this censorship, too. It varies greatly from country to country, more often censorship is used as an element of political influence on the society of a particular state. The social net- 
works that impose censorship must also take into account the legal field of the country where the office of the company holding such a network is registered. Thus, given all the above, we can see quite a contradictory picture. Returning to the thesis put forward at the beginning of the article, we should note that the very process of disseminating information creates censorship. This is true because new technological opportunities and their availability have allowed a huge number of people to express their opinions freely. But not all of these ideas are true, and in addition, people have begun to use Internet technology to manipulate and propagate. It follows that the free Internet, due to its freedom, becomes a powerful tool of manipulation, which in turn leads to the use of censorship.

Finally, we should consider a completely different type of censorship that does not fit into the standard understanding of the term. In general, censorship is a restriction on access to information. It is perceived as a negative phenomenon that restricts freedom. But in today's world, there is a new type of censorship, which, paradoxically, does not limit information, but contributes to its dissemination in large quantities. But society's attitude to this type of censorship is positive, because it is not considered censorship, but, on the contrary, is created seemingly for the comfort of millions of users.

It is necessary to begin with how all modern popular Internet resources or applications work. They encourage the user to spend as much time as possible on this site or application. Everything is subordinated to this goal, from interface design elements and technical solutions to the information that the user sees on the page. And even the order of data on the page and the form of retrieval of this information is calculated. The purpose of the management of Internet services is clear - the user's attention is drawn to show advertising, and the more advertising the user sees, the more reference Google or Facebook will earn.

In order to hold attention, it is necessary to publish content to which a person would respond. But there are a lot of people, and they are all very different, and how can we understand what exactly will the reference Vasya like, and what will Petya do? To this end, special recommendation algorithms have been developed. These are quite complex systems that are based on data analysis. The data itself is generated by users. Any action of the user is taken into account, from likes to the time of viewing the photo. Data can also be collected on third-party sites that do not appear to be affiliated with large corporations. Website owners themselves can add "pixels", a special program code that activates the collection of information about user actions on third-party sites. That is, when a user accesses the Internet, he is already closely watched by a certain type of machine, which transmits observation data for further analysis. All this large array of data is needed to create a virtual avatar of the user, which will predict his behavior. And these algorithms go very far, they can even determine the mood of the user and, using this knowledge, to program human behavior. Thus, it turns out that corporations are building a virtual maze, specially configured in such a way that the user could not, and most importantly would not want to leave it. The goal, as mentioned above, subordinates everything, from the design of the application to the content it contains.
We can certainly state that algorithms decide what a person wants before he realizes it. The content that the user sees is carefully selected by the algorithm, and therefore creates a subjective space in which each person will always receive only what he responds best. This subjective space is called an echo chamber or information funnel. This is the most powerful tool of modern censorship. At the same time, we call it a recommendation system and strive for its development, because it creates for us a comfortable space of interesting and relevant information. And if the recommendation system, for example, on music platforms cannot lead to dangerous consequences, then in terms of the system in general, we get a rather pessimistic picture. The example of music platforms illustrates this very vividly. Spotify or YouTube Music users are invited to select their favorite artists the first time they log in to the platform. Moreover, the list is updated instantly: by selecting one performer of a particular genre, the recommendation system will select several close-sounding artists. And even if the user chooses a rather wide range of musicians or genres of music, the one he pays the most attention to will dominate. It is clear that for music this approach can be useful, but the systems in other services work like that, even the news is adjusted to the preferences of the person. GoogleNews works like this: it displays popular local news and news selected according to the user's preferences. In fact, the user is flooded with information that will seem important and interesting, such a system does not leave the opportunity to see an alternative opinion. All this intensifies social polarization and destroys the possibility of dialogue in society. Thus, we have seen that, for example, Facebook notices information about vaccinations from COVID as one that needs to be clarified, but these are extremes that do not change the situation in general. We see that the problem is how modern Internet technologies work, not fake news. Also, the insidiousness of the systems is that they take into account the biological characteristics of the human subconscious. Moreover, modern technologies used for development are also designed to retain the user, albeit indirectly. By making changes to the algorithms and adding classical censorship, the main goal of the founders and holders of social networks remains the same: to attract people's attention to show them advertising. Therefore, the person will still remain in the echo chamber, where the algorithm is responsible for the information. This applies to literally the entire Internet and mobile development industry. It turns out that recommendation systems are ideal censorship: the user can get what he wants and miss everything else. And he cannot want something else precisely because he does not see anything else thanks to recommendation systems. A person simply does not have time to adapt to this new reality, because the development of technology is so rapid that it is physically impossible to capture it.

Let us look at TV as at the example of the speed of technology development. The first television network was established in 1928, and the TV itself has long been a luxury. Instead, Facebook was created in 2004, and in 2016 it was accused of influencing the minds of American citizens, threatening democracy. The democracy that originated in ancient Greece. Today we need to study the impact of new social networks and new data transmission 
formats on society. Such a network as TickTock has already gained a lot of popularity and continues to show a growing number of users. The form of presenting information in the format of short bright videos can have a special effect on the perception of information by a person, and in particular - by a child. In $2020,63 \%$ of TikTok users were between the ages of 10 and 29 (Mediakix; 2020).

We have a free space where people can express any opinion, but on the other hand, this space contains a lot of fakes and propaganda, in addition, the situation is complicated by what form of work has been chosen by services. Therefore, even the right thought may not reach people. All this suggests that the Internet is now in the socalled "Catch-22" (Akala, 2020). This catch symbolizes a hopeless situation when we have equivalent rules, but the implementation of one rule leads to the violation of another and vice versa. Striving for freedom and maximum representation, we open up opportunities for the spread of destructive and anti-social views, and even more, we are sometimes unable to identify exactly where the "true" information is and where the "false" information is.

This situation of uncertainty in society is widely explained by Ken Wilber in his book "Trump and a PostTruth World" (2019). In his opinion, the main postmodern slogan "There is no truth" is also embodied in modern technology. The crisis in society seems to be projected into cyberspace, where it continues its negative activities. And the virtual space itself, although it is a "global single brain", is used by ordinary individuals who have a whole range of human shortcomings. Also, this virtual space itself seems to provoke the user to make decisions of the type "or / or", i.e. "0 or 1". Given the natural subjectivity of human, this may lead to a strengthening of this trend (Wilber, 2019: 20-21).

The issue of crisis processes in society began to rise long before the Internet age. Today we see this crisis in terms of Internet technology. Johan Huizinga in his work "In the Shadow of Tomorrow", which was published in 1935, brought out the following problems in society: 1) the weakening of the ability to judge; 2 ) reduction of critical need; 3 ) rejection of the ideal of cognition (Huizinga, 2013: 19). Therefore, we see that the issue of dual censorship is one of the broader problems of humanity.

\section{Conclusions}

Thus, the research hypothesis stating that "availability of information generates censorship" was confirmed with the above arguments and examples from the work of social networks. The use of algorithms clearly demonstrates that people are no longer able to master all the information that they create. Censorship on the Internet is a complex and controversial phenomenon. It is an attempt to cure the symptom, not the disease itself. We traced this on the example of the use of various technical methods of blocking information or neglecting its value in social networks. In addition, non-technical and indirect methods of establishing a censorship framework for information in cyberspace have been analyzed. Their action can go beyond the established borders of states, as was the case with the use of the "China's Great Cannon". All methods are "adopted" by states and private institutions to limit the dissemination of "harmful" information. But we have seen that censorship today complicates access to information instead of completely blocking it. Thus, we have a "living and active contradiction": on the one hand, there is a flow of information on the Internet that we can use, and on the other hand, it is carefully monitored, dosed and influences the formation of our identity and socio-political position.

\section{REFERENCES}

Akala, A (2020). Don't Censor! Stop The Hoaxes! Facebook, Twitter Face A Catch-22. NPR: National Public Radio. https://www.npr.org/2020/10/16/924625825/dont-censorstop-the-hoaxes-facebook-twitter-face-a-catch-22.

Big Data from Kyivstar. https://kyivstar.ua/uk/business/products/big-data

CNews (2018, March 15) Twitter sluchayno zapretil Memfis [Twitter accidentally banned Memphis]. https://secretmag.ru/news/twitter-sluchaino-zapretilmemfis.htm.

CNews (2018, May 23). Twitter blokiruyet polzovateley, pishushchikh kirillitsey, kak «russkikh trolley» [Twitter blocks users writing in Cyrillic as "Russian trolls"] https://www.cnews.ru/news/top/2018-0523_twitter_blokiruet_vsehkto_ispolzuet_kirillitsu.

Demutska, A. V. (2021). Masovi emotsiyi $v$ sotsialnykh komunikatsiyakh yak resurs posylennya masovo informatsiynoho vplyvu. International scientific and practical conference. 32-38 (In Ukrainian).

Dodonova, V. I. (2019). Populizm i postpravda yak skladovi vyborchoho protsesu v Ukrayini. Kyyivski filosofski studiyi. 355-360 (In Ukrainian).

Freedom House. https://freedomhouse.org/country/ukraine/freedom-net/2020.

Harari, Yu. N. (2018). Homo Deus. Lyudyna bozhestvenna. Za lashtunkamy maybutnioho [trans. from English]. Kyiv: Book Chef, 512 p. (In Ukrainian)

Huizinga, Johan (2010). V teni zavtrashnego dnya. Chelovek i kultura. Zatemnennyy mir [trans. from. Netherland.]. St. Petersburg: Izdatelstvo Ivana Limbakha, 456 p. (In Russian)

Kholod, O. M. (2013). Sotsialni komunikatsiyi yak ponyattya v naukoviy haluzi "sotsialni komunikatsiyi". Psycholinguistics. 12: 286-293 (In Ukrainian).

Magun, A. V. (2011). Yedinstvo i odinochestvo. Kurs politicheskoy filosofii Novogo vremeni (Unity and loneliness. The course of political philosophy of modern times). Moscow: Novoye literaturnoye obozreniye $544 p$.

Marczak, B. \& Weaver, N. \& Dalek, J. \& Ensafi R. (2015). China's Great Cannon. The Citizen Lab University of Toronto. https://citizenlab.ca/2015/04/chinas-great-cannon/.

Mediakix (2020, June, 11). TOP 20 TIKTOK STATISTICS: KEY FACTS, FIGURES \& DATA. https://mediakix.com/blog/toptik-tok-statistics-demographic

Mlodinow, Leonard (2020). Pidsvidomist. Yak intuyityvnyy rozum lyudyny keruye yiyi povedinkoyu [trans. from English]. Kyiv: Hrupa KM-BUKS. 320 p. (In Ukrainian)

Muzhanova, T. M. (2015). Internet-tsenzura yak zahroza pravam hromadyan u sferi informatsiynoyi bezpeky. Suchasnyy zakhyst informatsiyi. $2: 84-88$.

O'Neill, Katie (2020). BIG DATA. Zbroya matematychnoho znyshchennya. Yak velyki dani zbilshuyut nerivnist zahrozhuyut demokratiyi. Kyiv: Fors Ukrayina, 2020. 336 p. (In Ukrainian)

Parish, Helen L. (2020). A Brief History: The Reformation [trans. from. English]. St. Petersburg: CoLibri, Azbuka-Atticus, 272 p. (In Russian)

Pichugina, Yu. O. (2011). Tsenzura v sotsialnokomunikatsiynykh kanalakh (ohlyad publikatsiy). Visnyk Kharkivskoyi derzhavnoyi akademiyi kultury. 34: 250-257 (In Ukrainian).

Radio Svoboda Ukrayina (2021, April 24). YouTube zablokuvav dostup do «kanaliv Medvedchuka» dlya ukrayinskykh korystuvachiv [YouTube has blocked access to Medvedchuk's channels for Ukrainian users] 
https://www.radiosvoboda.org/a/news-youtube-kanalymedvedchuka/31220540.html.

Radio Svoboda Ukrayina (2021, April 5). U Rosiyi prodovzhyly «upovil'nennya» merezhi Twitter [Russia has continued to "slow down" Twitter] https://www.radiosvoboda.org/a/newsrosija-twitter-upovilnennya/31187762.html.

Reporters Without Borders. https://rsf.org/en/ukraine.

Spero, J. (2017). How to make every mobile moment a brandbuilder. Think with Google. https://www.thinkwithgoogle.com/intl/en-cee/marketing- strategies/app-and-mobile/consumer-mobile-brand-contentinteraction/.

Sytnikova, I. (2021, April 21). U Malayziyi za «obrazu korolevy» zatrymaly khudozhnyka, yakyy drazhnyv yiyi pleylystom u Spotify [In Malaysia, for "insulting the queen" detained an artist who teased her playlist on Spotify]. Hromadske telebachennya. https://hromadske.ua/posts/u-malajziyi-zaobrazu-korolevi-zatrimali-hudozhnika-yakij-drazhniv-yiyiplejlistom-u-spotify.

Wilber, Ken (2019). Trump and a Post-Truth World. Kyiv: Terra Incognita, 136 p. (In Ukrainian)

Кирил Дзігора,

Credit Agricole Ukraine (Київ, Украӥна)

e-mail: dzihora.k@gmail.com,ORCID 0000-0002-8681-5467

\section{ЦЕНЗУРА В СОЦІАЛЬНИХ МЕРЕЖАХ ЯК СОЦІАЛЬНА ПРАКТИКА В УМОВАХ ГЛОБАЛЬНИХ ТРАНСФОРМАЦІЙ}

У статті з'ясовується соціально-фрілософський характер цензури, методи їі дії та обмеження, які вона може накладати на інформацію, представлену в соціальних мережах. Актуальність теми доведена аналізом наукових робіт та експертної думки 3 цієї тематики. Методологічним підгрунтям дослідження стали роботи 3 Інтернет-цензури та історії цензури, роботи про постправду, роботи про використання великих даних у повсякденному житті. На конкретних прикладах з роботи соціальних мереж автор доводить, що доступність інформації створює цензуру. Описано, яким чином віртуальний простір посилює суб'єктивність користувача. Виявлено складність та суперечливість явища цензури в Інтернеті. Також на прикладах зображено, як цензура змінює інформаційний простір для користувача. Проаналізовано технічні, нетехнічні та непрямі методи впровадження систем цензури для інформації в кіберпросторі. Більш детально у статті описані технічні методи цензури. Технічні методи було згруповано за такою класифікацією: такі, що уповільнюють дію сервісів; такі, що блокують дію сервісів; такі, що блокують інформацію за участю людини; такі, що блокують інформацію з використанням алгоритмів; позначення інформації як недостовірної. Усі методи проілюстровані прикладами, які доводять суперечливість явища цензури в Інтернеті. Зазначається, що цензура сьогодні ускладнює доступ до інформації, а не повністю блокує їі.

Розглянуто принцип роботи рекомендаційних систем, які створють новий тип цензури в Інтернеті. Цей новий тип цензури створено для комфорту користувача, а тому спільнота підтримує використання рекомендаційних систем. Зазначено, що використання цих систем посилює суб'єктивність у користувачів та призводить до створення ехо-камер. У висновках заначено, що дослідницька гіпотеза «доступність інформації породжує цензуру» знайшла підтвердження у наведених вище аргументах та прикладах 3 роботи соціальних мереж. Також розкрита сутність подвійного стану цензури в Інтернеті. 3 одного боку, у віртуальному просторі існує великий обсяг інформації, яка доступна для користування, а 3 іншого - вона ретельно відстежується, дозується і впливає на формування ідентичності та соціально-політичної позиції людини. Проблема цензури вписується у більш широкий пласт кризових процесів у суспільстві.

Ключові слова: Інтернет-цензура; інформаційна відкритість; постправда; методи цензури; криза в суспільстві; Інтернет-технології.

(C) Kyryl Dzihora

Надійшла до редакції: 04.05.2021

Прийнята до друку: 23.06.2021 